\title{
Depresjon og demens: en differensialdiagnostisk utfordring
}

\author{
Ved Uwe Ehrt og Dag Årsland
}

\section{Innledning}

Et av de mest bemerkelsesverdige demografiske utviklingstrekkene de senere årene er det sterkt $\varnothing$ kende antall eldre mennesker. I tillegg, og særlig i vesten, opplever vi at en stadig større andel av befolkningen blir eldre, noe som skyldes kombinasjonen av $\varnothing \mathrm{kt}$ levetid og synkende fødselsrate (Conwell, Duberstein, $\&$ Caine, 2002). Denne utviklingen medfører betydelige samfunnsmessige konsekvenser, ikke minst er den en utfordring for helsevesenet. Konsekvensene for det psykiske helsevern er store, også fordi forekomsten av mange psykiske lidelser $\varnothing$ ker proporsjonalt med alderen. Den praktiserende lege, det kan være allmennlege eller psykiater, blir ofte konfrontert med eldre pasienter som har både kognitive forstyrrelser og affektive symptomer. Depresjon og demens hører begge hver for seg til de hyppigste og mest alvorlige komplikasjoner ved aldring. I tillegg er det en komplisert og omfattende sammenheng mellom depresjon og demens: Disse to syndromer kan ha samme årsaksforhold og overlappende symptomatologi, depresjon gir $\varnothing \mathrm{kt}$ risiko for demens og omvendt, demens gir $\varnothing \mathrm{kt}$ risiko for depresjon. Prognose og behandlingsrespons er likevel svært forskjellig, og differensiering mellom demens og depresjon er en viktig

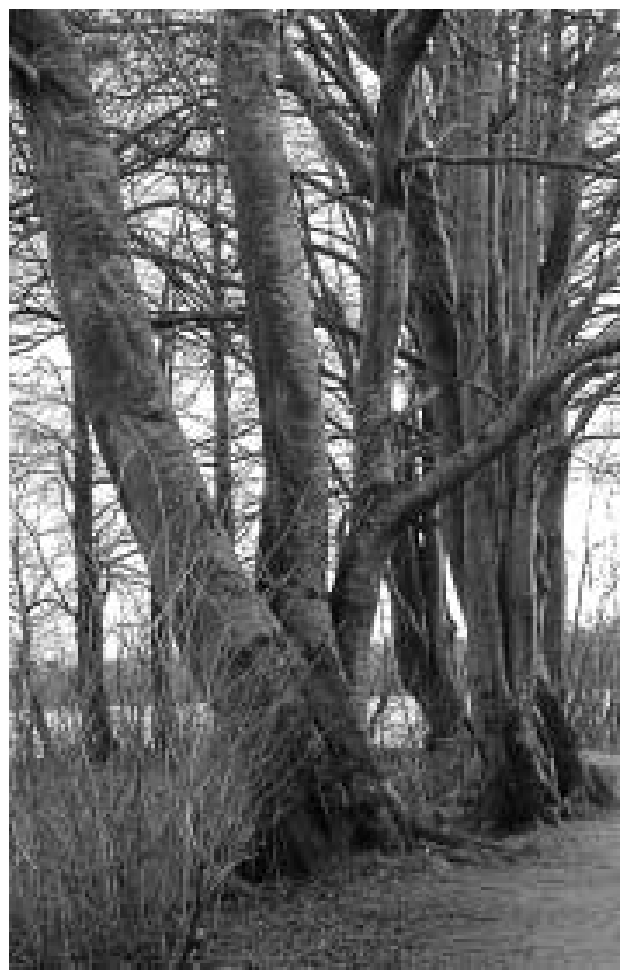

utfordring i klinisk medisin. Viktig er en grundig analyse av de psykopatologiske fenomenene for å integrere den i en omfattende og individuelt tilpasset behandlingsplan.

I denne artikkelen gjennomgås kort demens og depresjon hos eldre, differensialdiagnostikk mellom demens og depresjon, suicidalitet hos eldre og behandling av depresjon hos eldre med og uten demens.

\section{Demenslidelser}

Med demens betegnes svikt av minst to kognitive funksjoner ved klar bevissthet som er alvorlig nok til å påvirke pasientens evner og til å forårsake betydelige sosiale problemer. Psykiske og atferdsmessige forstyrrelser, som vandring, angst,

aggresjon og depresjon er hyppig, spesielt ved mer alvorlig demens.

Minst $50 \%$ av demenstilfellene er forårsaket av Alzheimers sykdom. Denne diagnosen er kjennetegnet ved progredierende hukommelsessvikt, afasi og apraksi. Fravær av fokale nevrologiske utfall støtter diagnosen. Vaskulær demens eller "multi-infarkt demens" er forårsaket av multiple subkortikale eller kortikale infarkter eller lakuner. Utviklingen her er ofte akutt eller trinnvis. Vaskulær demens utgjør $10-15 \%$ av det totale antallet demenstilfeller. Risikofaktorer for vaskulær demens er blant annet hypertensjon, karsykdom, diabetes mellitus, hjerneslag og røyking. Demens med Lewy-legemer opptrer i opptil $20 \%$ av alle demenstilfellene (McKeith, Perry, $\&$ Perry, 1999) og har et mer varierende symptombilde. I tillegg til kognitive forstyrrelser er parkinsonisme, synshallusinasjoner, fluktuerende kognisjon og falltendens hyppige. Hukommelsessvikt er ikke nødvendigvis framtredende i begynnelsen.

Det er viktig å fange opp de sjeldne tilfellene, hvor årsaken til demenstilstanden er mulig å behandle og tilstanden er potensielt reversibel, f.eks. normaltrykkhydrocephalus, subduralhematom, hjernetumor, encephalitt, hypothyreose og vitamin B12-mangel eller folatmangel. Depresjon er et vanlig fenomen ved alle demensformer og kan bli en vesentlig årsak til ytterligere funksjonssvikt og redusert livskvalitet.

\section{Depresjon hos eldre}

Depresjon regnes som den viktigste psykiske lidelsen blant eldre (Baldwin \& Simpson, 1997). Lenge trodde man at aldersdepresjon var klinisk annerledes enn vanlig depresjon. Kraepelin (1899) beskrev i den sammenheng tilstanden "involusjonsdepresjon", som etter hvert ble revidert av ham selv. Senere bekreftet Jules Angst (1966) at det ikke finnes noen generell og vesentlig forskjell mellom aldersdepresjon og vanlig depresjon.

Mens risikoen for å få en schizofreni, schizoaffektiv lidelse eller bipolar lidelse blir mindre når man blir eldre, er det ikke slik med unipolare depresjoner. Ulike studier har påvist varierende data for insidens og prevalens. Forsell \& Winblad (1998) fant klinisk signifikant depresjon hos $3.9 \%$ av ikke-demente og $11,8 \%$ blant demente eldre, mens et lavere funksjonsnivå var assosiert med depresjon i begge grupper. Weissman, Bruce, \& Leaf (1991) viste forekomst av alvorlig depresjon på $1 \%$ i en stor populasjonsbasert unders $\varnothing$ kelse blant personer eldre enn 65 år. Flere nyere studier taler mot den tidligere antakelsen at det er en $\varnothing \mathrm{kt}$ forekomst av depresjon i alderdommen (Chiu, Ames, Draper, \& Snowdon, 2001; Murphy, Laird, Monson, Sobol, \& Leighton, 2000), noen resultater tyder sågar på en heller lavere forekomst av alvorlig depresjon hos eldre (Blazer, 1994). Det er imidlertid viktig å være klar over at en stor andel eldre har klinisk betydningsfull og behandlingstrengende depresjon selv om de ikke nødvendigvis oppfyller DSM-kriteriene for alvorlig depresjon (Lebowitz et al., 1997).

Hyppig terapiresistens (Baldwin \& Simpson, 1997), somatisk komorbiditet (Beekman et al., 1997), dårlig prognose (Beekman et al., 2002), muligheten til å utvikle en demenslidelse (Nahas, Kunik, Orengo, Molinari, \& Workman, 1997) og en høyere suicidrate gjør aldersdepresjonen til en særdeles vanskelig utfordring for pasienter, pårørende, psykiatere og sykehjemspersonell.

\section{Demens og depresjon - differensialdiagnostikk}

I alderspsykiatrien ser man hyppig pasienter som har både affektive og kognitive symptomer. Da er man konfrontert med 
den differensialdiagnostiske oppgaven å sette syndromene demens og depresjon i en etiologisk eller kausal relasjon. Dette er en vesentlig forutsetning for å kunne behandle pasienten adekvat.

Avgjørende er pasientens sykehistorie og en grundig somatisk og psykiatrisk utredning. Man bør fokusere på symptomutvikling ved sykdomsdebut, forl $\varnothing p$ (inkludert fluktuasjon og varighet av symptomene), funksjonsnivå (også i forhold til pasientens sosiale nettverk) og inntak av medisiner. Unders $\varnothing$ kelsen suppleres av en mer eller mindre omfattende nevropsykologisk unders $\varnothing$ kelse. Det er omstridt hvorvidt en skal teste en depressiv pasient som lett kan oppfatte testingen som belastende. Dessuten kan resultatene bli påvirket gjennom depresjonsrelaterte kognitive forstyrrelser. Mini-Mental-Testundersøkelsen (Folstein, Folstein, \& McHugh, 1975) er en enkel kognitiv test som gir god mulighet til både å vurdere pasientens kognitive funksjoner og å observere ham eller henne under unders $\varnothing \mathrm{k}$ elsen. Depressive pasienter uten demens gir gjerne "jeg vet ikke"-svar. Mangel på evne til å tegne som uttrykk for visuellspatial svikt eller grov svikt av orientering tyder derimot heller i retning av en demenslidelse.

På symptomnivå er det overlapping mellom depresjon og demens (se figur 1). Ikke sjelden ser man pasienter som er deprimerte og som samtidig er tilsynelatende preget av kognitiv svikt. Viktige symptomer som $s \varnothing$ vnforstyrrelser, appetittendringer, apati eller angst kan prege begge lidelser.

Figur 1: Overlapping mellom symptomene ved depresjon og demens

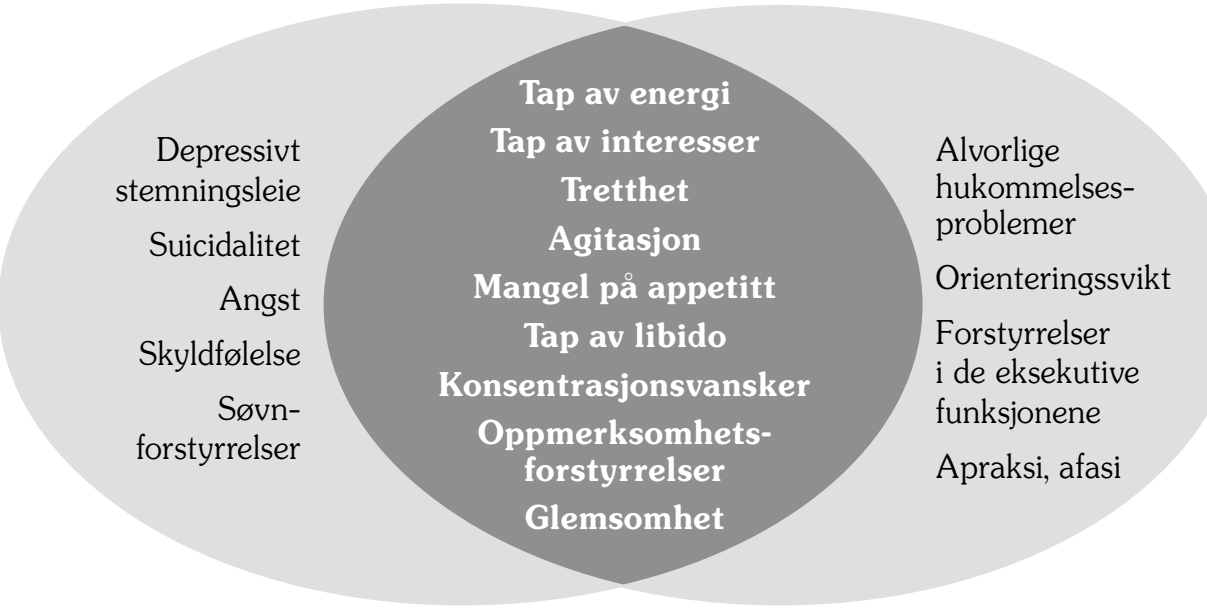

føre hyppigere til depresjon enn infarkter andre steder i hjernen (Dobie, 2002).

Det er ingen klar relasjon mellom alvorlighetsgrad av demens og forekomst av depresjon, men et lavt funksjonsnivå disponerer for depresjon. Overlapping mellom depresjon og demens er særlig tydelig ved Parkinsons sykdom (Tandberg, Larsen, Aarsland, \& Cummings, 1996).

4. D epresjonen kan forårsake strukturelle forandringer som medfører demens (f.eks. hippocampusatrofi).

Man vet at depresjon i seg selv er en viktig risikofaktor for å utvikle en demenslidelse. Longitudinelle studier har vist at en ikke ubetydelig andel eldre med depresjon og pseudodemens senere utvikler en "ekte" demens. Alexopoulos et al. viste at $43 \%$ av deprimerte med en reversibel pseudodemens i løpet av gjennomsnittlig 34 måneder utviklet irreversibel demens, mens dette var tilfellet for bare $12 \%$ av dem uten pseudodemens. Ingen andre kliniske karakteristika skilte gruppene (Alexopoulos, Meyers, Young, Mattis, \& Kakuma, 1993). I en gruppe eldre deprimerte som hadde hatt kognitiv svikt som var normalisert etter antidepressiv behandling, fikk 89 \% diagnosen Alzheimers sykdom ved en oppfølgingsundersøkelse 8 år senere (Kral \& Emery, 1989).

\section{En alvorlig depresjon kan være preget av kognitiv og funksjonell svikt, slik at man klinisk ikke er i stand til å skille mellom tilstandene.}

Ofte blir fenomenet "pseudodemens" diskutert i denne sammenhengen. Opprinnelig brukte man begrepet for å karakterisere hysteriske tilstander, hvor pasientene viser en atferd som en ukyndig ville oppfatte som "gal". Slike tilstander inngår i dag i gruppen "dissosiative lidelser".

Kiloh (1961) brukte begrepet senere for å karakterisere reversible tilstander med kognitiv svikt som er følge av funksjonelle psykiske lidelser. Etter hvert brukte man begrepet "depressiv pseudodemens" som synonym for kognitive forstyrrelser ved depresjon som kan simulere en demenslidelse. Cummings (1989) anbefalte heller å bruke begrepet "demenssyndrom ved depresjon" ("dementia syndrome of depression") istedenfor "pseudodemens", som er uklart og kan gi feilaktige implikasjoner. 
Opptil $20 \%$ av eldre deprimerte synes å utvikle utpregede kognitive symptomer. Risikofaktorer for kognitiv svikt ved depresjon er sen depresjonsdebut og demens i familien (Dobie, 2002). Vanligvis er de kognitive symptomene milde og domineres av psykomotorisk retardasjon og oppmerksomhetsforstyrrelser, lettere hukommelses- og konsentrasjonsvansker, mens kal kulasjon og orientering er intakt. O fte faller depresjonssymptomene og de beskrevne kognitive problemene tydelig sammen i tid ( $M$ arneros, 2004).

I praksis er det ofte ikke mulig, eller det er kontraindisert å utsette en alvorlig deprimert pasient for omfangsrik nevropsykologisk testing. Derfor mangler vi ofte differensierte nevropsykologiske data for deprimerte. H eller ikke biologiske markører, som f.eks dexamethasonsuppresjonstesten, klarer å skille sikkert mellom begynnende demens og pseudodemens. O fte er det observasjon av tilstanden over tid som gir svaret.

Det faktum at mange deprimerte som er preget av kognitiv svikt, dvs "pseudodemens", senere utvikler genuin demens, er et argument for å gå bort fra begrepet "pseudodemens". A ndre argumenter er at begrepet a) minner om en diagnostisk kategori, som det ikke er; b) blir brukt i forskjellige sammenhenger (hysterisk demens, simulasjon, reversibel forvirring under delirium, reversibel kognitiv svikt ved depresjon); c) bare kan brukes retrospektivt og d) impliserer en organisk/funksjonell dikotomi som kan hindre en integrert tilnærming (D obie, 2002).

\section{Depresjon som følge av omsorgssvikt}

Eldre blir ofte ofre for omsorgssvikt på sykehjem, men det kan også skje i deres eget hjem hvis de er aleneboende. Rammet er særlig de eldste av de eldre med demens og de som er uten pårørende. Personalmangel på sykehjem er en ytter-ligere risikofaktor. Slike faktorer kan gi depresjon eller andre atferdsforstyrrelser som igjen kan bli årsak til frustrasjon og aggresjon hos personalet.

\section{Suicidalitet hos eldre}

Det finnes begrenset forskning på suicidalitet hos eldre. En vanlig oppfatning er at suicid i denne aldersgruppen hovedsakelig skyldes al vorlig sykdom eller andre håpløse situasjoner, og anses således som forståelig og uunngåelig. M en de data som finnes, viser at de fleste eldre som gjennomfører suicidforsøk har psykiatriske lidelser eller sliter med vanskelige sosiale situasjoner eller somatiske sykdommer, tilstander som ofte kan påvirkes.

Suicidforsøk hos eldre er gjennomsnittlig mer alvorlige enn hos yngre og ender sål edes hyppigere fatalt ( $C$ onwell et al., 2002), og eldre utgjør den delen av befolkningen som har den høyeste selvmordsraten. Data fra W HO viser at el dre hvite menn mellom 80 og 85 år har den høyeste selvmordsraten. Det antas at omtrent 65 individer per 100000 i denne gruppen tar livet av seg per år. Suicidmetoder varierer med alder, kjønn og sosiokulturelle faktorer. M ens eldre kvinner oftest tar livet av seg ved forgiftning, er henging den vanligste metoden blant eldre menn i Storbritannia. $60 \%$ av selvmord blant menn i USA blir gjennomført ved skyting.

Ensomhet er en viktig sosial risikofaktor. Ekteskap virker beskyttende, mens det blant enker og særlig enkemenn er størst selvmordsrisiko det første året etter ekte-

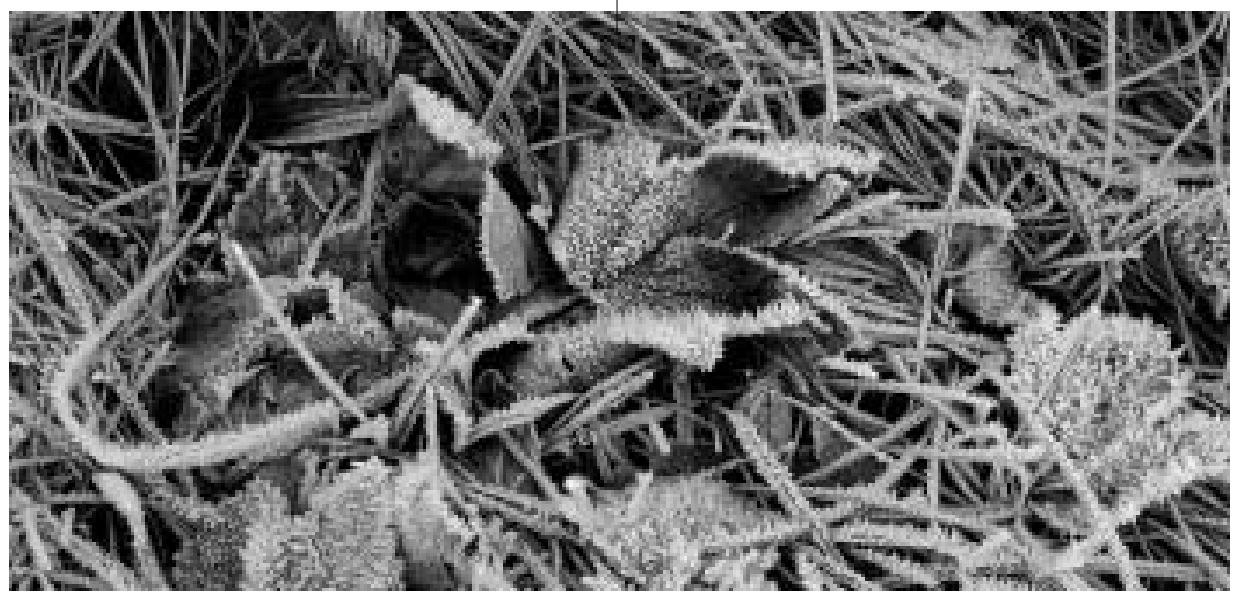

fellens død (H. C attell, 1994). Det er en større forekomst av suicid i lavere sosiale lag. O pptil $90 \%$ av personer som behandles etter suicidforsøk eller som fullfører suicid, har depresjon, og de fleste studier har utpekt depresjon som den viktigste risikofaktoren (M urphy \& M CD onald, 1992). Conwell og Brent (1995) viste at relativt flere el dre enn yngre led av depresjon før selvmordet. Søvnløshet, vekttap og skyldfølelse var de mest framtredende symptomer før suicid (Barraclough $\&$ Pallis, 1975). Såkal te "rasjonelle" suicid synes å være sjeldne ( C attell, 1994)

A ndre psykiatriske lidel ser, som alkoholavhengighet eller personlighetsforstyrrelser er relatert til suicidalitet i omtrent lik stor grad hos eldre som hos yngre (C attell, 1994; C onwell, R oten berg, \& Caine, 1990). Suicid hos eldre synes å være korrelert i sterkere grad enn hos yngre til somatisk sykdom. Særlig smertetilstander øker risikoen. Cattell (1988) fant at $21 \%$ av en gruppe eldre som hadde tatt sitt eget liv, hadde hatt en sykdom som forårsaket smerte.

$\mathrm{N}$ år man skal vurdere suicidalitet hos eldre er det viktig å forstå pasientens verdisystem, forholdet til religion, oppfatninger om eutanasi og graden av håpløshetsfølel se i forhold til framtiden. Dette er viktige faktorer i forhold til kognitive psykoterapeutiske strategier.

Er det en sammenheng mellom suicidalitet og demens? Tidligere studier har vist en økt prevalens av mild demens hos suicidale (Sainsbury, 1962), mens al vorlig demens heller er en beskyttelsesfaktor (Copas \& Robin, 1982). Tilsvarende er det relativt sjelden at man finner demente blant personer som har gjort suicid ( $C$ onwell $\&$ Pearson, 2002). I en studie ønsket $4 \%$ av 221 pasienter med A Izheimers sykdom enten å være død eller å ta livet av seg (Draper, M acC uspie-M oore, \& Brodaty, 1998).

Selvmordshyppigheten blant eldre er lavere i N orge enn i de fleste andre vestlige land. M en også i N orge er selvmordsrisikoen størst blant eldre $(27,8 / 100000$ i perioden 1991-1995 vs. 20,5/100000 i hele befolkningen) (Kjølseth, Ekeberg, \& Teige, 2002). I en omfattende studie anal yserte Kjølseth et al. (2002) 287 tilfeller av suicid blant eldre (>65år) som var undersøkt ved Rettsmedisinsk institutt, Rikshospitalet, fra 1992 til 2000. 
Studien viste at $62 \%$ hadde en psykiatrisk diagnose fra før, $41 \%$ led av depresjon. Somatisk sykdom var den antatte årsaken i $22 \%$ av tilfellene. Mange av pasientene hadde kontakt med helsepersonell før suicidet. En stor del hadde ytret selvmordsplaner, noe som er en viktig påminnelse til klinikere om å kartlegge depresjon og suicidalitet grundig.

\section{Behandling}

Differensieringen mellom demens og depresjon er også relevant når man skal vurdere terapeutiske muligheter. I løpet av de siste 10-15 årene har vi som behandler pasienter med demens opplevd en ny situasjon. Med kolinesterasehemmerne $(\mathrm{KEH})$ kan man tilby pasientene en evidensbasert virksom terapi. Selv om resultatene ikke er tilfredsstillende enda, kan man dog si at i hvert fall en betydelig del av pasientene har nytte av behandlingen. Ikke minst pår $\varnothing$ rende opplever det positivt at pasienten får tilbud om medisinsk behandling. Tidligere var pasientene mer eller mindre utlevert til sykdommens naturlige forl $\varnothing \mathrm{p}$.

$\mathrm{KEH}$ har vist seg virksomme særlig $\mathrm{i}$ tidlige stadier av demens. Derfor er det viktig at primærhelsetjenesten diagnostiserer demens så tidlig som mulig. Memantin, en NMDA-reseptorantagonist, er blitt godkjent i Norge som middel som kan forsinke progresjonen av moderat til alvorlig demens. Det er viktig å integrere vår viten om risikofaktorer i helsepedagogiske tiltak og opplæring av befolkningen. Risikofaktorer som kan påvirkes er høyt blodtrykk, hyperkolesterolemi og overvekt. Middelhavskost og kroppslig og mental aktivitet virker beskyttende, forenklet sagt: et sunt liv.

Psykose og atferdsforstyrrelser er hyppige symptomer ved demens. Tidligere ble slike symptomer ofte behandlet med dempende lavpotente eller klassiske høypotente nevroleptika. I den senere tid har man heller brukt de nyere, atypiske nevroleptika. Nylig er det påvist $\varnothing \mathrm{kt}$ risiko for slag eller hjerte-kar-sykdommer etter medisinering med moderne antipsykotika hos eldre. Mangel på tilfredsstillende alternativer er hovedgrunnen til at situasjonen oppleves fatal av mange som jobber i alderspsykiatrien. Basert på de data som finnes, har en gruppe av norske spesialister utarbeidet (foreløpige) retningslinjer for bruk av antipsykotika hos eldre (Statens legemiddelverk, 2004). Muligens vil vi i tiden framover igjen rette mer fokus mot miljørelaterte og psykologiske terapiformer Selv om depresjon er hyppig ved demens og selv om mange demente pasienter med depresjon får antidepressiva, er det mer klinisk erfaring enn vitenskapelig evidens som st $\varnothing$ tter denne praksisen. Dette konkluderte en Cochrane-oversikt med, som understreket viktigheten av å gjennomføre større studier på depresjonsbehandling hos demente (Bains, Birks, \& Dening, 2002). Uansett er det viktig å understreke at man skal være liberal med å behandle depressive symptomer hos eldre, uavhengig av om pasienten også har kognitiv svikt. Man vet at heller for få enn for mange demente pasienter med depresjon får adekvat behandling. En kontrollert studie av 279 demente viste at $51 \%$ av dem som oppfylte kriteriene for diagnosen alvorlig depresjon, ikke fikk medikamentell antidepressiv behandling (Evers et al., 2002).

Depresjon hos eldre uten demens behandles ikke prinsipielt annerledes enn hos yngre. Psykofarmakologiske tiltak må nevnes først, selv om responsraten skal være litt lavere enn hos yngre. Uavhengig av substansklassen fører antidepressiver hos omtrent 60-70 \% av de eldre til en forbedring av de depressive symptomene (placebo responsraten skal ligge ved 30 $40 \%$ ) (Szanto et al., 2002). Man kan ikke si generelt at den ene substansklassen virker bedre enn den andre. Individuelle forskjeller er store. Hos både demente og ikke-demente eldre med depresjon er serotoninreopptakshemmere (SSRI) det vanligste medikamentet pga. gunstig bivirkningsprofil med lite antikolinerge effekter (Avorn, 1998). Studier på enkelte substanser har vist at for eksempel sertralin (SSRI) (Lyketsos et al., 2003) og moclobemid (MAOH-hemmer) (Roth, Mountjoy, \& Amrein, 1996) er virksomme. Det samme viste Teri et al. (1994) for ikke-medikamentelle, psykoterapeutiske behandlingsformer. I tillegg er SSRI lettere å administrere enn eldre midler, og de er mindre toksiske.

Ved vedvarende eller gjentatte depresjoner burde en prøve stemningsstabili- serende substanser. At litium virker profylaktisk mot suicid er klassisk viten (Schou, 2000).

Elektrokonvulsiv terapi (EKT) er godt tolerert og effektiv mot depresjon hos eldre. Siden mange eldre har komorbide somatiske lidelser, er antidepressiva ofte kontraindisert. I disse tilfellene burde man tidlig i forløpet overveie EKT (Hay, 1989). Psykoterapi (særlig interpersonell terapi, kognitiv atferdsterapi, ressursorientert samtaleterapi) ble vurdert ved mild til mellomgradig depresjon som likeverdig til psykofarmakoterapi hos eldre (Niederehe, 1994).

\section{Oppsummering}

Demens og depresjon er de to viktigste psykiske lidelsene hos eldre. Mens demens preges av kognitive symptomer, er depresjon i klassisk forstand en affektiv lidelse. Men symptomene respekterer ikke våre tradisjonelle klassifikasjonssystemer. Derfor kan det være vanskelig å skille mellom depresjon og demens, særlig tidlig i forløpet. Det er nyttig å være klar over mulige konstellasjoner hvor syndromene opptrer samtidig. Denne koeksistensen er heller vanlig enn uvanlig. For å kunne tilby best mulig behandling er det viktig å analysere årsaksforhold, vekselvirkning og mulige kausale sammenhenger mellom begge tilstander.

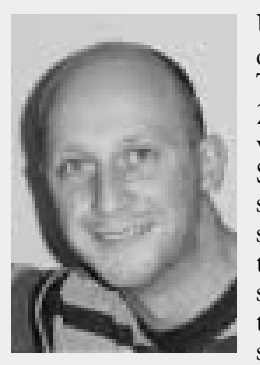

U we Ehrt er psykiater og psykoterapeut fra Tyskland og har siden 2002 jobbet som overlege ved Psykiatrisk klinikk, Stavanger Universitetssjukehus (SUS) Han har siden 2003 vært tilknyt tet Alderspsykiatrisk seksjon. I 2004 fikk han tildelt et doktorgradsstipend fra Helse Vest.

Fokus i hans forskning er depresjon ved Parkinsons sykdom.

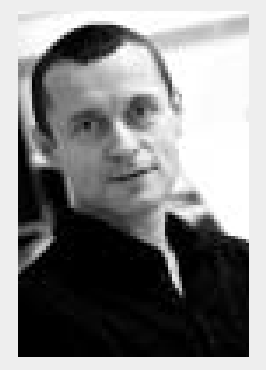

D ag Å rsland er seksjonsoverlege ved Alderspsykiatrisk seksjon,Psykiatrisk klinikk, Stavanger Universitetssjukehus (SUS) og leder for Senter for alders- og nevropsykiatrisk forskningssenter ved SUS. Han er også professor II i alderspsykiatri ved Universitetet i Bergen. 


\section{Referanser}

A lexopoulos, G. S., M eyers, B. S., Young, R. C., M attis, S., \& Kakuma, T. (1993). T he course of geriatric depression with "reversible dementia": a controlled study. A m J Psychiatry, 150 (11), 1693-1699.

A ngst, J. (1966). Zur Ä tiologie und N osologie endogener depressiver Psychosen. Berlin $\mathrm{H}$ eidel berg $\mathrm{N}$ ew York: Springer.

A vorn, J. (1998). D epression in the elderly - falls and pitfalls. N Engl J M ed, 339(13), 918-920.

Bains, J., Birks, J. S., \& Dening, T. R. (2002). The efficacy of antidepressants in the treatment of depression in dementia. Cochrane Database Syst $\operatorname{Rev}(4), C D 003944$

Baldwin, R. C., \& Simpson, S. (1997). Treatment resistant depression in the elderly: a review of its conceptualisation, management and relationship to organic brain disease. J A ffect Disord, 46(3), 163-173.

Ballard, C. G., Cassidy, G ., Bannister, C., \& M ohan, R. N . (1993). Prevalence, symptom profile, and aetiology of depression in dementia sufferers. J A ffect Disord, 29(1), 1-6.

Barraclough, B. M ., \& Pallis, D. J. (1975). D epression followed by suicide: a comparison of depressed suicides with living depressives. Psychol M ed, 5(1), 55-61.

Beekman, A. T., G eerlings, S. W., Deeg, D. I., Smit, J. H., Schoevers, R. S., de Beurs, E., et al. (2002). T he natural history of late-life depression: a 6-year prospective study in the community. A rch G en Psychiatry, 59(7), 605-611.

Beekman, A . T., Penninx, B. W., Deeg, D. J., Ormel, J., Braam, A . W., \& van Tilburg, W. (1997). Depression and physical health in later life: results from the L ongitudinal A ging Study A msterdam (LA SA ). J A ffect Disord, 46(3), 219-231.

Blazer, D. G . (1994). D ysthymia in community and clinical samples of older adults. A m J Psychiatry, 151(11), 1567-1569.

Cattell, H . (1994). Suicidal B ehaviour. In J. R. M. Copeland, M. T. A buh-Saleh \& D. G. Blazer (Eds.). Principles and Practica of $G$ eriatric Psychiatry. London: John W iley \& Sons Ltd.

Cattell, H. R. (1988). Elderly Suicides in London. Int. J. G eriatr. Psychiatry, 3, 251-261.

Chiu, E., A mes, D., Draper, B., \& Snowdon, J. (2001). D epressive disorders in the elderly. In M. M aj \& N . Sartorius (Eds.), Depressive disorders. W PA series evidence and experience in psychiatry. Chichester: John Wiley \& Sons.

Conwell, Y., \& Brent, D. (1995). Suicide and aging. I: Patterns of psychiatric diagnosis. Int Psychogeriatr, 7(2), 149-164.

Conwell, Y., Duberstein, P. R., \& Caine, E. D. (2002). R isk factors for suicide in later life. Biol Psychiatry, 52(3), 193-204.

Conwell, Y., \& Pearson, J. L. (2002). T heme issue: suicidal behaviors in older adults. A $\mathrm{m}$ J G eriatr Psychiatry, 10(4), 359-361.
Conwell, Y., Rotenberg, M., \& Caine, E. D. (1990). C ompleted suicide at age $\mathbf{5 0}$ and over. J $A \mathrm{~m}$ G eriatr Soc, 38(6), 640-644.

Copas, J. B., \& Robin, A . (1982). Suicide in psychiatric in-patients. Br J Psychiatry, 141, 503 511.

C ummings, J. L. (1989). D ementia and depression: an evolving enigma. J $\mathrm{N}$ europsychiatry $\mathrm{C}$ lin N eurosci, 1(3), 236-242.

Dobie, D. J. (2002). D epression, dementia, and pseudodementia. Semin Clin N europsychiatry, 7(3), 170-186.

D raper, B., M acC uspie-M oore, C., \& Brodaty, H. (1998). Suicidal ideation and the 'wish to die' in dementia patients: the role of depression.

A ge A geing, 27(4), 503-507.

Evers, M. M., Samuels, S. C., Lantz, M., Khan, K., Brickman, A. M ., \& M arin, D. B. (2002). The prevalence, diagnosis and treatment of depression in dementia patients in chronic care facilities in the last six months of life. Int I G eriatr Psychiatry, 17(5), 464-472

Folstein, M . F., Folstein, S. E., \& M cH ugh, P. R. (1975). "Mini-mental state". A practical method for grading the cognitive state of patients for the clinician. J Psychiatr Res, 12(3), 189-198.

Forsell, Y., \& Winblad, B. (1998). Major depression in a population of demented and nondemented older people: prevalence and correlates. I A m G eriatr Soc, 46(1), 27-30.

H ay, D. P. (1989). Electroconvulsive T herapy in the Medically III Elderly. Convuls Ther, 5(1), 8-16.

Kiloh, L. G . (1961). Pseudo-dementia. A cta Psychiatr Scand, 37, 336-351.

Kjolseth, I., Ekeberg, O ., \& Teige, B. (2002). Selvmord blant eldre i N orge. Tidsskr N or Laegeforen, 122(15), 1457-1461.

Kraepelin, E. (1899). Psychiatrie. Ein Lehrbuch für Studirende und $A$ erzte. (6. A uflage ed.). Leipzig: Johann A mbrosius Barth.

Kral, V. A ., \& Emery, O. B. (1989). Long-term follow-up of depressive pseudodementia of the aged. C an J Psychiatry, 34(5), 445-446.

Lebowitz, B. D., Pearson, J. L., Schneider, L. S., Reynolds, C. F., 3rd, A lexopoul os, G. S., Bruce, M. L., et al. (1997). D iagnosis and treatment of depression in late life. C onsensus statement update. Jama, 278(14), 1186-1190.

Statens legemiddelverk. (2004). M edikamentell behandling av atferdsforstyrrelser og psykologiske symptomer (BPSD) hos personer med demens. (23.12.04) http://www.legemiddelverket.no/terapi/ 2004/BPSD-demens.htm

Lyketsos, C. G., DelC ampo, L., Steinberg, M., M iles, Q., Steele, C. D., M unro, C., et al. (2003). Treating depression in A Izheimer disease: efficacy and safety of sertraline therapy, and the benefits of depression reduction: the DIA DS. A rch Gen Psychiatry, 60(7), 737-746.
M arneros, A . (2004). Bipolare und depressive Erkrankungen des höheren Lebensalters. In A . $M$ arneros ( $E d_{\text {. }}$ ), $H$ andbuch der bipolaren und depressiven Erkrankungen. Stuttgart, N ew York: Thieme.

M cKeith, I. G ., Perry, E. K ., \& Perry, R. H . (1999). $R$ eport of the second dementia with Lewy body international workshop: diagnosis and treatment Consortium on Dementia with Lewy Bodies. N eurology, 53(5), 902-905.

M urphy, C., \& M cD onald, A . (1992). A ffective disorders in old age. In E. Paykel (Ed.), $H$ andbook of A ffective Disorders. Edinburgh, London, M adrid, Melbourne, N ew York, Tokyo: C hurchill Livingstone.

M urphy, J. M ., Laird, N. M ., M onson, R. R., Sobol, A. M., \& Leighton, A. H. (2000). A 40-year perspective on the prevalence of depression: the Stirling C ounty Study. A rch G en Psychiatry, 57(3), 209-215.

$\mathrm{N}$ ahas, Z., Kunik, M. E., O rengo, C. A ., M olinari, V., \& W orkman, R. (1997). Depression in male geropsychiatric inpatients with and without dementia: a naturalistic study. J A ffect Disord, 46(3), 243-246.

N iederehe, G . (1994). Psychosocial therapies with depressed older adults. In L. S. Schneider, C. F. Reynolds, B. D. Lebowitz \& et.al. (Eds.), Diagnosis and Treatment of Depression i Later Life. W ashington: A merican Psychiatric Press.

Nilsson, F. M., Kessing, L. V., Sorensen, T. M ., A ndersen, P. K., \& Bolwig, T. G. (2002). Enduring increased risk of developing depression and mania in patients with dementia. $\mathrm{J} N$ eurol $\mathrm{N}$ eurosurg Psychiatry, 73(1), 40-44.

Roth, M ., M ountjoy, C. Q ., \& A mrein, R. (1996) M oclobemide in elderly patients with cognitive decline and depression: an international doubleblind, placebo-controlled trial. Br J Psychiatry, 168(2), 149-157.

Sainsbury, P. (1962). Suicide in later life. G erontol Clin (Basel), 4, 161-170.

Schou, M. (2000). Suicidal behavior and prophylactic lithium treatment of major mood disorders: a review of reviews. Suicide Life Threat Behav, 30(3), 289-293.

Szanto, K., Gildengers, A ., M ulsant, B. H., Brown, G., A lexopoulos, G. S., \& Reynolds, C. F., 3rd. (2002). Identification of suicidal ideation and prevention of suicidal behaviour in the elderly. Drugs A ging, 19(1), 11-24.

Tandberg, E., Larsen, J. P., A arsland, D., \& C ummings, J. L. (1996). T he occurrence of depression in Parkinson's disease. A communitybased study. A rch N eurol, 53(2), 175-179.

Teri, L. (1994). B ehavioral treatment of depression in patients with dementia. A lzheimer Dis A ssoc Disord, 8 Suppl 3, 66-74.

Weissman, M . M., Bruce, M. L., \& Leaf, P. J. (1991). A ffective D isorders. In L. N . Robins \& D. A . Regier (Eds.), Psychiatric Disorders in A merica (pp. 53-80). N ew York: Free Press. 